\title{
EFFECT OF THE INTERNAL SIZE AND THERMAL INSULATION OF THE HIVE ON BEE COLONIES STRENGTH AND PRODUCTIVITY
}

\author{
ABD-ELMAWGOOD, B. H., M. A. AL-RAJHI and A. O. EL-ASHHAB
}

Ag. Eng. Res. Institute, AnERI, ARC. El-Dooki-Egypt.

(Manuscript received 12 January 2015)

\begin{abstract}
$\mathrm{T}$ his study was conducted to investigate the effect of the internal size and thermal insulation of the hive on bee colonies strength (sealed brood area) and productivity (honey area, pollen area). Hives from Langstroth type were used containing honeybee colonies of equal strength from the species of hybrid carniolan. This study included three internal sizes of bee hives $\left(0.024,0.031\right.$ and $\left.0.038 \mathrm{~m}^{3}\right)$; three insulation cases (without, with sackcloth and with foam); and three hive entrance direction (East, Southeast and South). The lowest mean hive temperatures recorded in the middle of January to be $18.3,16.8$ and $11.8^{\circ} \mathrm{C}$ with foam, sackcloth and without insulation, respectively. Average lower temperature were $20,16.7$ and $13.6^{\circ} \mathrm{C}$ for internal hive sizes of $0.024,0.031$ and $0.038 \mathrm{~m}^{3}$, respectively. Average temperature were $17.3,16.9$ and $16.6^{\circ} \mathrm{C}$ for hive entrance direction South, Southeast and East, respectively. The mean area of honey, pollen and sealed brood at the end of March were 826, 652 and $3561 \mathrm{~cm}^{2}$, respectively when using foam insulator. And 884, 716 and 3626 $\mathrm{cm}^{2}$, respectively at the end of March and with internal hive size $0.024 \mathrm{~m}^{3}$. In case of south entrance direction the above areas were 845,658 and $3542 \mathrm{~cm}^{2}$, respectively at the end of March. Significant increase in hive temperature, honey area, pollen area, sealed brood area was detected When using the lowest internal beehives size and foam insulator.

Key words: Insulating, temperature, honey area, pollen area and sealed brood area.
\end{abstract}

\section{ITRODUCTION}

Temperature is an important factor affecting larval and pupal development of insects (Nylin and Gotthard, 1998). Honeybees can survive when the temperature of the external environment is between -20 and $+48{ }^{\circ} \mathrm{C}$ and even -40 and $+60{ }^{\circ} \mathrm{C}$. However, they show the best performance at the temperatures between +21 and $+35^{\circ} \mathrm{C}$. If the temperature is extremely cold in winter (falls below $+14^{\circ} \mathrm{C}$ ) bees do not move around to collect honey (carbohydrate source) and pollen (protein source) and forming a ball (winter cluster). When the temperature falls below $+6^{\circ} \mathrm{C}$, the hive has the appearance of an exact ball Adaptation to cold climates does not involve a state of dormancy or hibernation characteristic of most insects; honeybees remain active within the winter cluster. The cluster center, or core, in broodless colonies is generally maintained within the range of $20-30^{\circ} \mathrm{C}$. Maintaining a suitable range of temperature 
from 33 to $36{ }^{\circ} \mathrm{C}$ inside colonies is very important for honeybees (Petz et. al. 2004). This constant temperature is crucial for the normal growth and development of the brood. Deviation from this range can occur when the ambient air temperature changes and affect the developmental period of honey bee immature stages, emergence rate (Tautz et. al. 2003) Also, ambient temperature has a great effect on foraging activity (Al-Qarni 2006 and Blazyte-Cereskiene et. al. 2010). Moreover, very low temperature below $10^{\circ} \mathrm{C}$ can prevent flight activity (Joshi and Joshi 2010). So crucial is the perception of temperature change to bees that an individual worker is able to pick up changes to within $0.25^{\circ} \mathrm{C}$ using receptors located on her antennae (Mathis and Tarpy, 2007). Honeybees are known to control their hive environment to survive drastic changes in the field environment (Jones and Oldroyd, 2007). During flight, the rather large flight muscles create heat, which must dissipate to brood area (Esch et. al., 1991). The brood nest needs temperature of $30-36^{\circ} \mathrm{C}$ to develop the brood Stabentheimer et. al., 2003 used a new infrared technology, were able to measure the temperature of the individual parts of bees bodies, and show that there were also some workers who actually made heat (thermogenesis) by "shivering" (activating their wing muscles).Nest heating has an energetic cost: when ambient temperature drops from $28-17^{\circ} \mathrm{C}$, the metabolic rate of a bee colony rises from $7-$ 19 watt $\mathrm{kg}^{-1}$. It has been demonstrated that, at low temperatures, workers spend more energy and time for thermoregulation than for brood care (feeding, building brood cells), which results in a reduced production of brood by the colony. Moreover, it has been shown that the production of brood cells is lower during cold periods of the year compared to hot periods (Velthuis et. al.,2000; Borges and Blochtein, 2006). Colonies even completely interrupt the production of brood cells during the period of winter (van Benthen et. al.,1995). At low ambient temperatures, whenever the brood temperature drops below the needed range of temperature, worker honeybees engage in different strategies to warm up the brood. One such strategy they employ is to heat their thoraces through muscular activity and press their warm thoraces onto capped brood cells for several minutes at a time (Bujok et. al., 2002), such honeybees are referred as cap heating honeybees. The second strategy the worker honeybees employ is to warm themselves up, to enter empty comb cells among the brood, and to dissipate their body heat to the brood cells around them (Kleinhenz et. al.,2003); such honeybees are referred to as cell heating honeybees. In both the case of cell and the cap heating honeybees, the bees increase their body temperature by isometrical contraction of the bee flight muscles (Seeley, 1995 and Crane, 1990). In addition to these heating strategies, the honeybees also try to insulate and reduce the heat loss from the brood by crowding in the brood area. The main hypothesis to explain why brood production diminishes during cold periods is that workers spend more energy in heating the colony than with tasks related to brood production (Engels et. al.,1995; Vogt, 1996). Bees consume honey to rise inside the hive temperature in Worker bees contribute to the regulation of brood nest temperature by producing heat while sitting 
motionless on the caps of brood cells (Marco Kleinhenz et. al., 2003). Increasing levels of metabolism ( $\mathrm{i}$ e, honey consumption for heat production) are indeed associated with exposure to cold temperatures. The adult bees begin to generate their own heat by consuming carbohydrates (in the form of stored honey) and as a result they go hungry also in some cases they cannot feed themselves because honey within the hive freezes due to the cold. Starvation is a principal cause of colony losses; they cluster and starve because they eat the honey that stored. Therefore, if bees are short of honey, they should be fed a syrup of two parts granulated sugar to one part water that increase costs of production. Factors of external ambient and internal hive conditions are very important on the productivity honeybees (Cetin, 2004). Morse, 1990 mentioned that hives in cellar wintering, a technique that was often used at the turn of the past century. While only one of the variables of the equation, food consumption, is measured, the hive temperature increased, when they are moved to a relatively warmer place. When the hives are outside they consume 22.3 kilograms of honey during the season, but when they are placed in a cellar they only consume 6.8 to 13.2 kilograms. Starks et. al.,2000 observed that honeybees raise the temperature of the brood area regularly to increase the brood activities and protect themselves against predators. They have also stated that when Ascosphaera apis which is the pathogen of chalk brood contaminates to the colony at the temperatures below $30^{\circ} \mathrm{C}$, honeybees realize this and raise the temperature before the broods get sick. There have been many attempts to reduce the loss of honey bee colonies in winter, by improving the conditions of temperature inside the bee colonies, such as:(Furgala, and McCutcheon, 1992, Abrol, 2001,Wineman et. al., 2003, Dodologlu, et. al., 2004 and Erdogan, et. al., 2009. Morse, 1999) recommended keeping bee colonies in the Northern U.S. during the winter in dark-painted hives and exposed to full sunlight, but provided no experimental data to indicate any beneficial effect of such a treatment. There are little researches about warming of beehives under Egypt condition. Bees or adult population was estimated in the rate of 2000 adult bees, which can cover a comb from both sides (Hauser and Lensky, 1994).

Therefore, the objective of the present study was to select the best internal size and thermal insulating of the hive that should be used to decrease both colony food consumption and mortality by improving hive conditions and maintaining the strength of colonies to produce citrus honey early during spring season.

\section{MATERIALS AND METHODS}

Bees from a private apiary at Meet-Salseel, EL- Daqahliyah governorate, Egypt, were used in this study. Langstroth beehives or otherwise known as movable frame hive is one of the types of hive designed for rearing honeybees for economic benefit. This type of hive is the most widely used hive in the world (Ojeleye, 1999). A total of 21 Langstroth enclosure beehives (outside measures: $53 \mathrm{~cm} \times 43 \mathrm{~cm} \times 25 \mathrm{~cm}$ 
and wall thickness: $2 \mathrm{~cm}$ ) with removable tops contents honey bees (hybrid carniolan), that had been established 8 months prior to the onset of the experiment on a sunny site in the bee yard, with their entrances far from the common wind direction and rain. Beehives were equal in the strength, food stores (Honey - pollen), queen's age (about 8 months old) and number of combs covered with bees from both sides (6 combs). Nosema apis and Varroa destructor were monitored every 12 days throughout the winter season, and treated whenever necessary. The present study carried out from 1 December until 30 March.

The studied factors included three internal sizes of beehives $(0.024,0.031$ and $0.038 \mathrm{~m}^{3}$ ); three insulation cases (without, with sackcloth and foam); and three hive entrance direction (East, Southeast and South). There were two ventilation small holes located under the cover to permit ventilation and allow moisture exchange. A digital thermometer was used to determine internal hive temperature in the bee yard. The number of sealed brood cells located at the lower edge or sides of the comb, honey stored along the top edge of the comb and pollen stored along the sides of the comb. Each colony was monitored by taking photos of the new sealed brood, honey and pollen cells after shaking the bees off (fig. 1). Comparing consecutive the number of new sealed brood, honey and pollen cells photos could be assessed. The nearest areas of capped brood, honey and pollen cells were determined in all the experimental colonies by considering 4 cells per sq. $\mathrm{cm}$ of comb. This investigation was carried out every 12 days throughout the winter season of 12 December, 24 December, 5 January, 17 January, 29 January, 10 February, 22 February, 6 March, 18 March and 30 March.
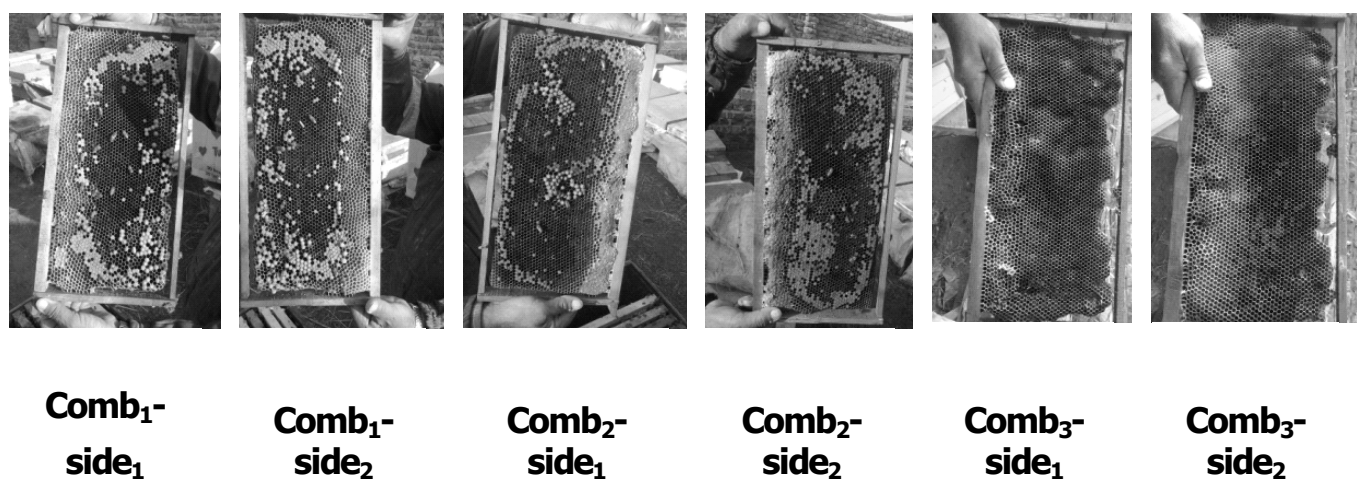

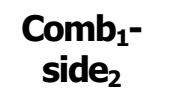

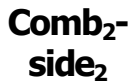

$\mathrm{Comb}_{3}-$ side $_{1}$

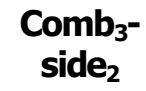

Fig. 1. Some combs inspected in winter season.

\section{RESULTS AND DISCUSSION}

\section{1- The climate of tested region.}

Data illustrated in figures from 2 to 4 show the mean monthly climatic factors for the 4 months (December 2013, January 2014; February 2014 and March 2014). The range of minimum temperature fluctuated between $10.7^{\circ} \mathrm{C}$ in January and 14.9 
${ }^{\circ} \mathrm{C}$ in March Maximum temperature fluctuated between $18.8^{\circ} \mathrm{C}$ in January to $22.8^{\circ} \mathrm{C}$ in March. The aerage temperature during night time in December, January, February and March was $15.4,13.4,15$ and $16.8{ }^{\circ} \mathrm{C}$, respectively. The mean temperature during daytime in December, January, February and March was 17.9, 15.9, 17.5 and $19.7^{\circ} \mathrm{C}$, respectively. Out of 1294 possible sunshine duration hours during the study so, the ambient temperature was higher than $8^{\circ} \mathrm{C}$. In general, workers cease flying when ambient temperature is below $8^{\circ} \mathrm{C}$ (Crane, 1990), hence, the winter of 20132014 was quite favorable for foraging activities of field bees. The minimum value of mean rainfall was $0 \mathrm{~mm}$ in February and March; and the maximum value was $32 \mathrm{~mm}$ in January. The average wind velocity during December, January, February and March was 3.2, 3.4, 3.5 and $4.1 \mathrm{~m} / \mathrm{sec}$., respectively. In general, the activity of foragers stops at wind velocities above nine $\mathrm{m} / \mathrm{sec}$. (Hoopingarner and Waller, 1992), but wind velocity never reached that value during the study. The average Relative humidity, \% during December, January, February and March was 75, 76, 74 and $67 \%$, respectively as illustrated in Figs (2,3 and 4$)$.

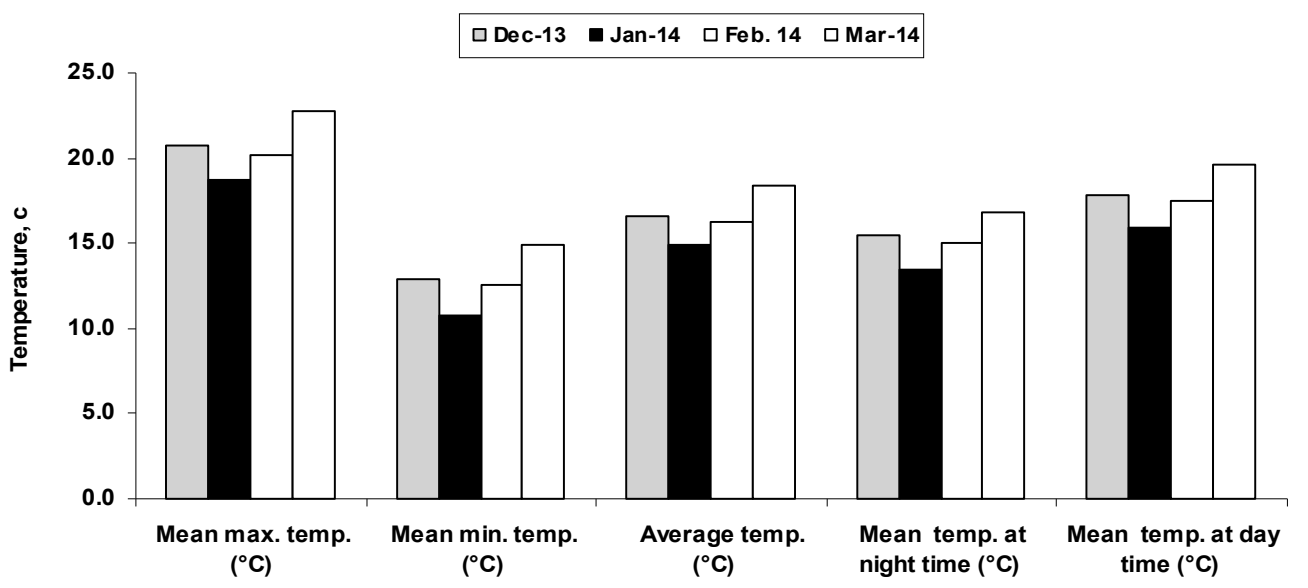

Fig. 2. The mean temperatures during the study.

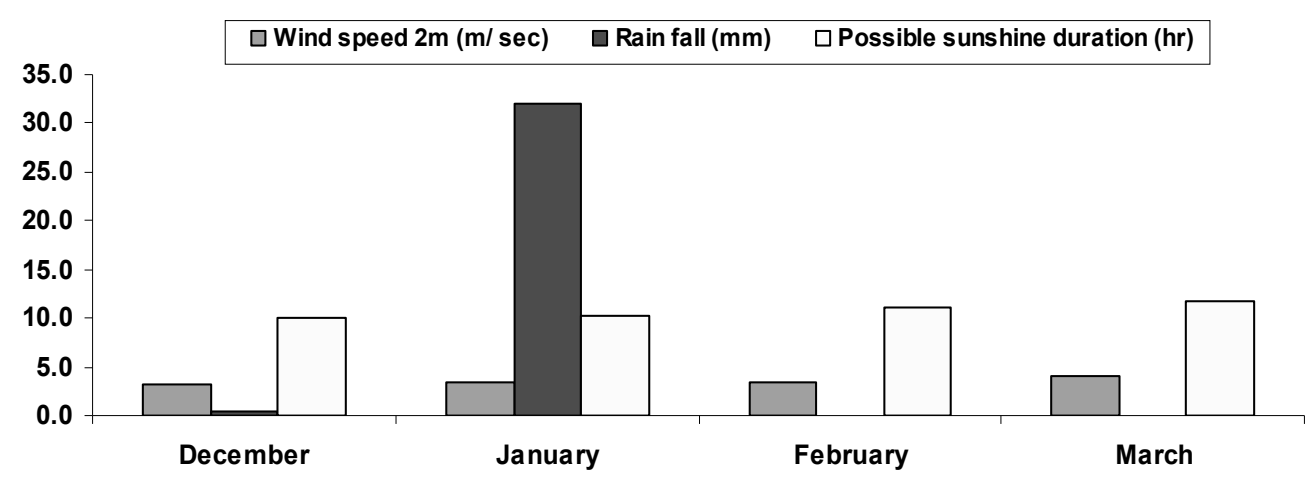

Fig. 3. The mean wind speed $(\mathrm{m} / \mathrm{s})$, rainfall $(\mathrm{mm})$ and possible sunshine duration (hr) during the 4 months. 


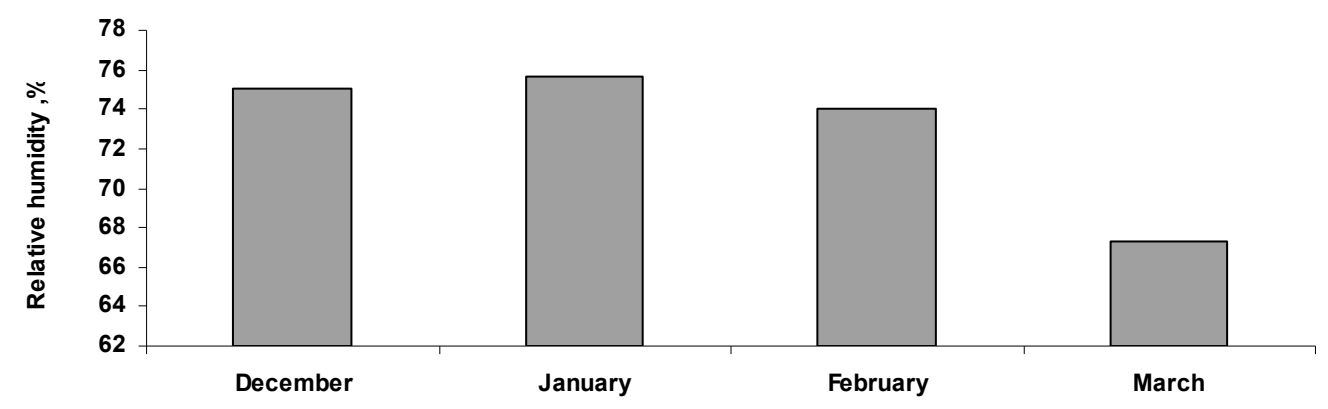

Fig. 4. The mean relative humidity, $\%$ during the 4 months.

Data illustrated in Figs (5 to 8 ) show the comparative magnitude of values of hive temperature $\left(\mathrm{T},{ }^{\circ} \mathrm{C}\right)$, honey area, $\left(\mathrm{H}_{\mathrm{a}}, \mathrm{cm}^{2}\right)$, polen area, $\left(\mathrm{P}_{\mathrm{a}} \mathrm{cm}^{2}\right)$ and sealed brood $\left(\mathrm{Sb}_{\mathrm{a}}, \mathrm{Cm}^{2}\right)$.

\section{2- Effect of the internal hive size, insulator type and hive entrance direction on hive temperature, ${ }^{\circ} \mathrm{C}$.}

Fig. 5 shows the effect of internal hive size, insulator type and hive entrance direction temperature. There was an increasing in temperature when decreasing hive internal size and by using foam insulator with South entrance direction. The mean temperature on the middle of January increases from $13.6^{\circ} \mathrm{C}$ at hive internal size $0.038 \mathrm{~m}^{3}$ to $20^{\circ} \mathrm{C}$ at hive internal size $0.024 \mathrm{~m}^{3}$. The mean temperature on the middle of January increases from $16.8{ }^{\circ} \mathrm{C}$ with sackcloth insulator to $18.3^{\circ} \mathrm{C}$ with foam insulator, however sackcloth insulator prevents any foreign insect from interning the hive and absorb vapor from the evaporation process. The lower mean temperature on the middle of January was $11.8^{\circ} \mathrm{C}$ without using insulator. The mean temperature on the middle of January increases from $16.6^{\circ} \mathrm{C}$ at East entrance direction to $17.3^{\circ} \mathrm{C}$ at South entrance direction. In general, the average values were decreased for all from the first day of experiment (12 December, 2013) up to the nearly middle of January (17 January, 2014) then increased from the end of January (29 January, 2014) up to the end of experiment (30 March, 2014). This is due the effect of changes in ambient temperature during the study. It was noticed that $\mathrm{T},{ }^{\circ} \mathrm{C}$ increased; with internal hive sizes, insulator types and entrance direction, according to the following descending order $\left(0.038 \mathrm{~m}^{3}<0.031 \mathrm{~m}^{3}<0.024 \mathrm{~m}^{3}\right)$; ( without insulator $<$ Sackcloth $<$ Foam) and (East $<$ Southeast $<$ South), respectively. 


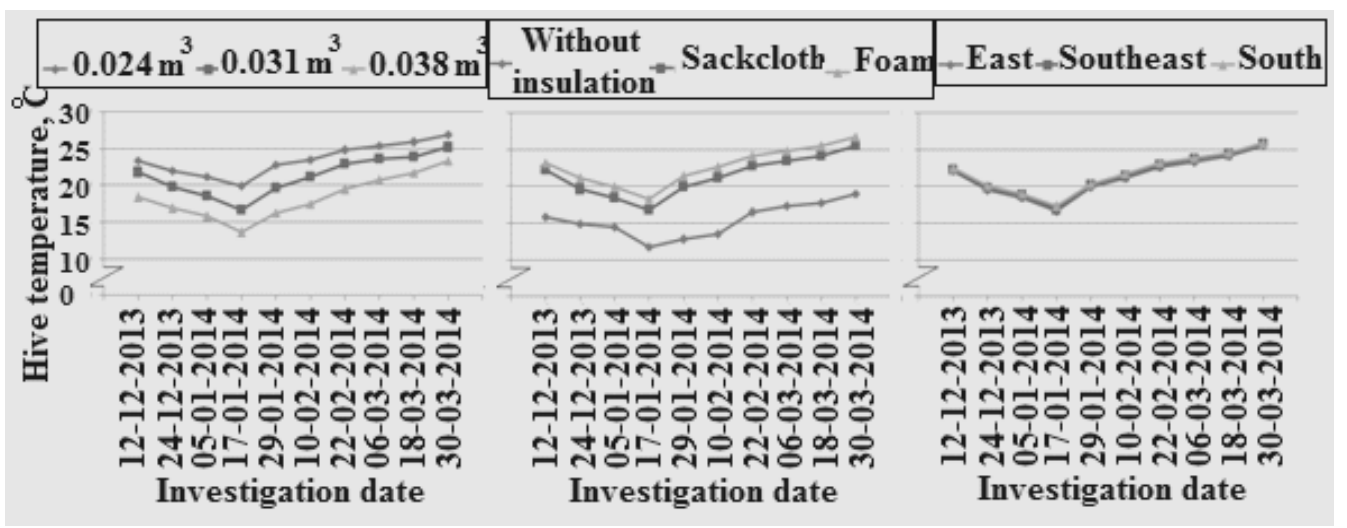

Fig. 5. Effect of the internal hive size, insulator type and hive entrance direction on hive temperature, ${ }^{\circ} \mathrm{C}$

\section{3- Effect of the internal hive size, insulator type and hive entrance direction on honey area.}

The mean value of honey area, $\mathrm{cm}^{2}$ Fig. 6 increased on the end of March from $555 \mathrm{~cm}^{2}$ at hive internal size $0.038 \mathrm{~m}^{3}$ to $884 \mathrm{~cm}^{2}$ at hive internal size $0.024 \mathrm{~m}^{3}$. The mean honey area, $\mathrm{cm}^{2}$ on the end of March increases from $126 \mathrm{~cm}^{2}$ with sackcloth insulator to $128 \mathrm{~cm}^{2}$ with foam insulator. The mean honey area, $\mathrm{cm}^{2}$ on the end of March was $284 \mathrm{~cm}^{2}$ without using insulator. The mean honey area, $\mathrm{cm}^{2}$ on the end of March increases from $800 \mathrm{~cm}^{2}$ with East entrance direction to $845 \mathrm{~cm}^{2}$ with South entrance direction. In general, the average values were decreased for all from the first day of experiment (12 December, 2013) up to the nearly middle of January (17 January, 2014) and started to increase from the end of January (29 January, 2014) up to the end of experiment (30 March, 2014). This is due the effect of changes in ambient temperature during the study. It was noticed that honey area, $\mathrm{cm}^{2}$ increased; with internal hive sizes, insulator types and insulator thicknesses, according to the following descending order $\left(0.038 \mathrm{~m}^{3}<0.031 \mathrm{~m}^{3}<0.024 \mathrm{~m}^{3}\right.$ ); (without insulator $<$ Sackcloth $<$ Foam) and (East < Southeast $<$ South), respectively.

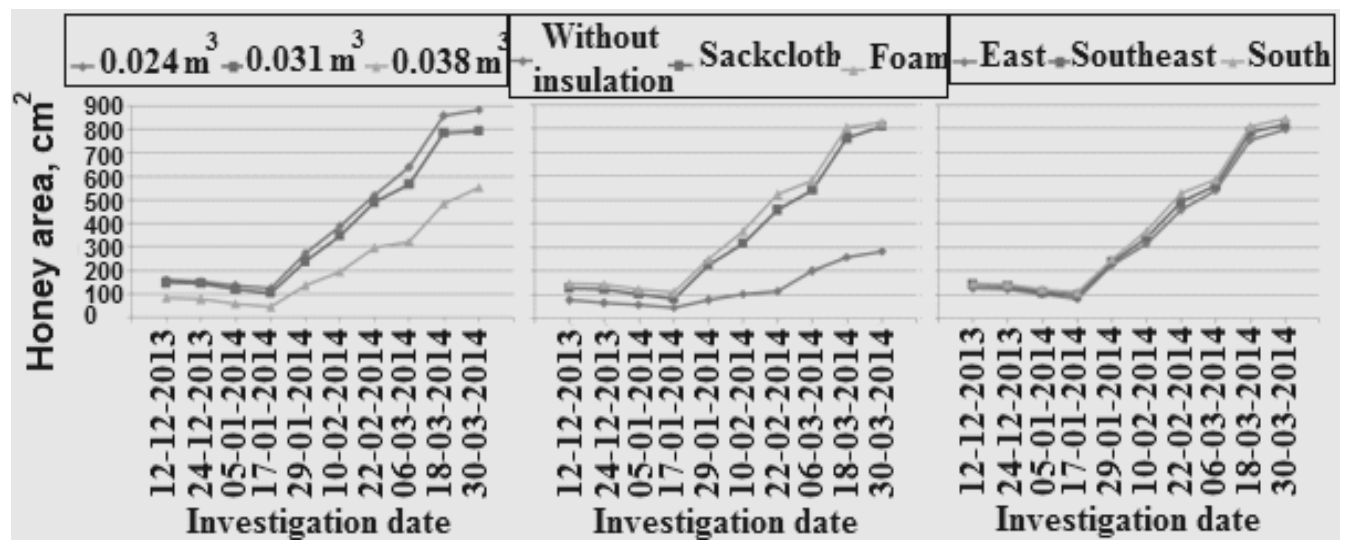

Fig. 6. Effect of the internal hive size, insulator type and hive entrance direction on honey area, $\mathrm{cm}^{2}$ 


\section{4- Effect of the internal hive size, insulator type and hive entrance direction on pollen area.}

The mean value of pollen area, $\mathrm{cm}^{2}$, Fig. 7 increases on the end of March from $477 \mathrm{~cm}^{2}$ at hive internal size $0.038 \mathrm{~m}^{3}$ to $716 \mathrm{~cm}^{2}$ at hive internal size $0.024 \mathrm{~m}^{3}$. The mean pollen area, $\mathrm{cm}^{2}$ on the end of March increases from $574 \mathrm{~cm}^{2}$ with sackcloth insulator to $652 \mathrm{~cm}^{2}$ with foam insulator. The mean pollen area, $\mathrm{cm}^{2}$ on the end of March was $406 \mathrm{~cm}^{2}$ without using insulator. The mean pollen area, $\mathrm{cm}^{2}$ on the end of March increases from $619 \mathrm{~cm}^{2}$ with East entrance direction to $658 \mathrm{~cm}^{2}$ with South entrance direction. In general, the average values were decreased for all from the first day of experiment (12 December, 2013) up to the nearly middle of January (17 January, 2014) and started to increase from the end of January (29 January, 2014) up to the end of experiment (30 March, 2014). This is due the effect of changes in ambient temperature during the study. It was noticed that pollen area, $\mathrm{cm}^{2}$ increased; with internal hive sizes, insulator types and insulator thicknesses, according to the following descending order $\left(0.038 \mathrm{~m}^{3}<0.031 \mathrm{~m}^{3}<0.024 \mathrm{~m}^{3}\right)$; (without insulator < Sackcloth $<$ Foam) and (East $<$ Southeast $<$ South), respectively.

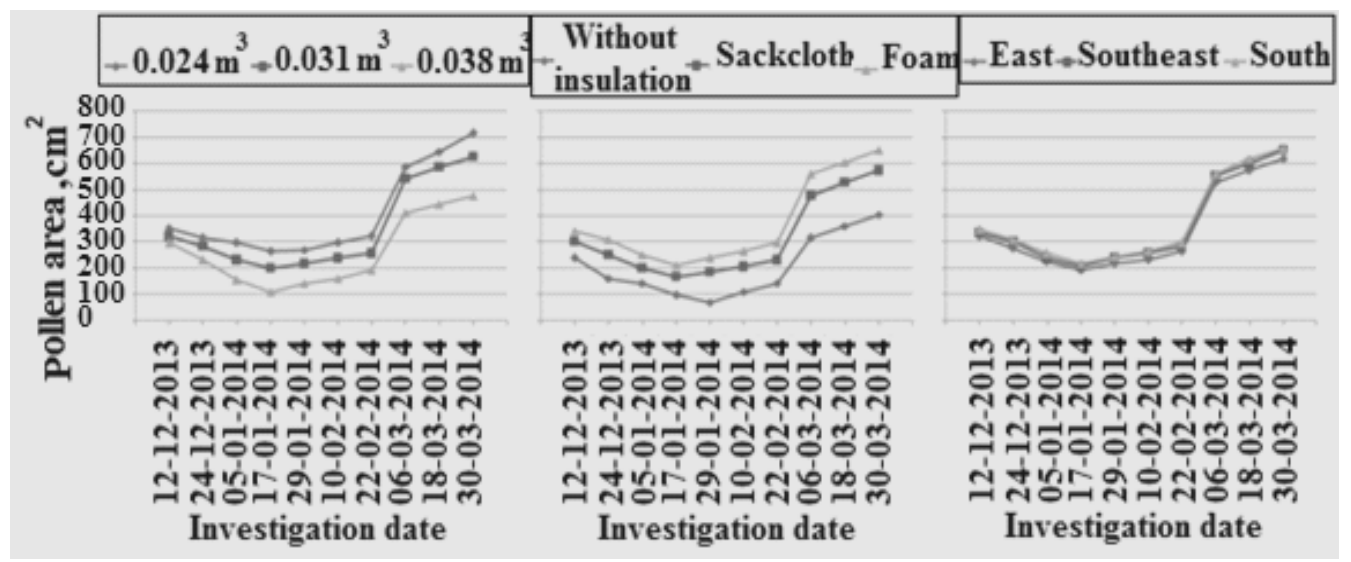

Fig. 7 . Effect of the internal hive size, insulator type and hive entrance direction on pollen area, $\mathrm{cm} 2$

\section{5- Effect of the internal hive size, insulator type and hive entrance direction on sealed area brood, $\mathbf{c m}^{2}$.}

The mean value of sealed brood area, $\mathrm{cm}^{2}$, Fig. 8 increases on the end of March from $3168 \mathrm{~cm}^{2}$ at hive internal size $0.038 \mathrm{~m}^{3}$ to $3626 \mathrm{~cm}^{2}$ at hive internal size 0.024 $\mathrm{m}^{3}$. The mean sealed brood area, $\mathrm{cm}^{2}$ on the end of March increases from $3503 \mathrm{~cm}^{2}$ with sackcloth insulator to $3561 \mathrm{~cm}^{2}$ with foam insulator. The mean sealed brood area, $\mathrm{cm}^{2}$ on the end of March was $2710 \mathrm{~cm}^{2}$ without using insulator. The mean sealed brood area, $\mathrm{cm}^{2}$ on the end of March increases from $3452 \mathrm{~cm}^{2}$ with East entrance direction to $3542 \mathrm{~cm}^{2}$ with South entrance direction. In general, the average values were decreased from (24 December, 2013) up to the nearly end of January (29 January, 2014) and started to increase from the end of January (29 January, 2014) up to the end of experiment (30 March, 2014. It was noticed that sealed brood area, $\mathrm{cm}^{2}$ 
increased; with internal hive sizes, insulator types and insulator thicknesses, according to the following descending order $\left(0.038 \mathrm{~m}^{3}<0.031 \mathrm{~m}^{3}<0.024 \mathrm{~m}^{3}\right.$ ); (without insulator $<$ Sackcloth $<$ Foam) and (East $<$ Southeast $<$ South), respectively.

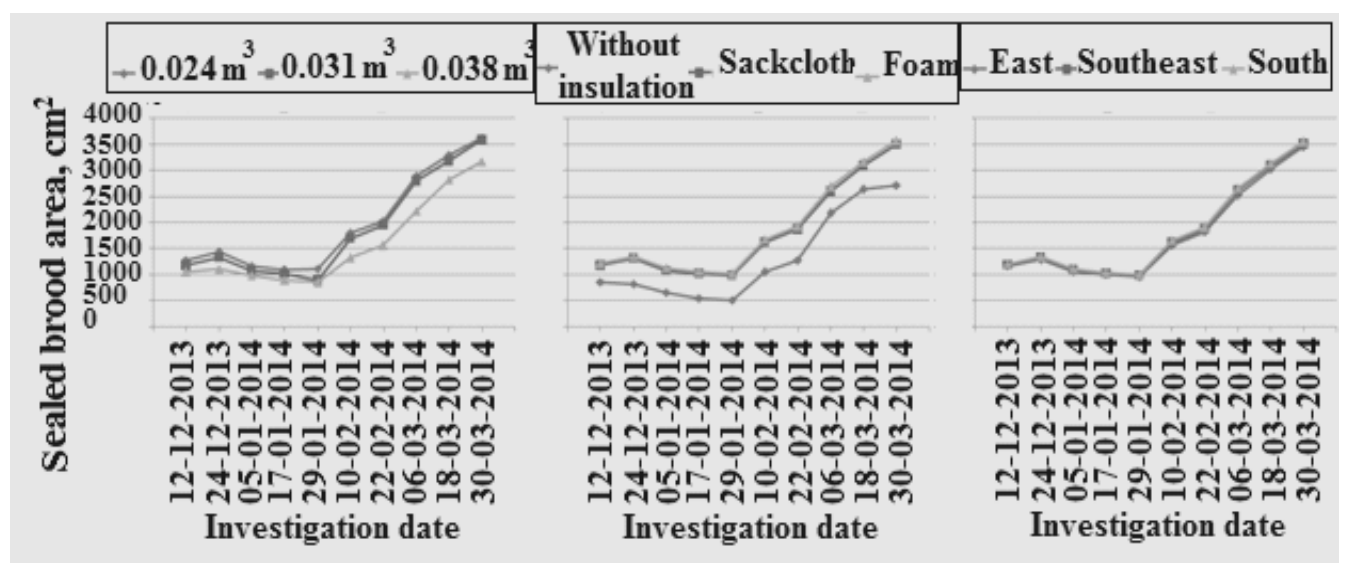

Fig. 8. Effect of the internal hive size, insulator type and hive entrance direction on sealed brood area, $\mathrm{cm}^{2}$

\section{CONCLUSION}

It was observed that the maximum values of hive temperature, area of honey, pollen and sealed brood were achieved by using the lowest internal beehives size $\left(0.024 \mathrm{~m}^{3}\right)$ and the South entrance direction.

\section{REFERENCES}

1. Abrol, D.P. 2001. Utilization of waste materials for outdoor wintering of Apis mellifera L. colonies.Bioresource Technology, 81: 159-161.

2. Al-Qarni A.S. 2006. Tolerance of summer temperature in imported and indigenous honeybee Apis mellifera L. races in central Saudi Arabia. Saudi J. Biol. Sci. 13: 123-127.

3. Blazyte-Cereskiene L., G. Vaitkeviciene, S. Venskutonyte, V. Buda. 2010. Honey bee foraging in spring oilseed rape crops under high ambient temperature conditions. Zemdirbyste-Agriculture 97: 61-70.

4. Borges, F V B; and B. Blochtein. 2006. Variação Sazonal das condições internas de colônias de Melipona marginata obscurior Moure, no Rio Grande do Sul, Brasil. Revista Brasileira de Zoologia 23 (3): 711-715

5. Bujok, B. M. Kleinhenz, S. Fuchs, and J. Tautz. 2002. Hot spots in the bee hive. Naturwissenschaften 89 (7), 299-301.

6. Cetin, U. 2004. The effects of temperature changes on bee losts. Uludag Bee J., 4 (4): 171-174.

7. Crane, E. 1990. Bees and Beekeeping: Science and practice, and world resources. Comstock Pub. Associates Ithaca, NY. 
8. Dodologlu, A., C. Dulger and F. Gene. 2004. Colony condition and bee behavior in honey bees (Apis mellifera L.) housed in wooden or polystyrene hives and fed bee cake or syrup. J. Apicult. Res., 43: 3-8.

9. Engels, W; P. Rosenkranz; and E. Engels. 1995. Thermoregulation in the nest of the neotropical stingless bee Scaptotrigona postica and a hypothesis on the evolution of temperature homeostasis in highly eusocial bees. Studies in Neotropical Fauna and Environment 30(4): 193-205.

10. Erdogan, Y., D. Ahmet and E. Boma. 2009. Some Physiological Characteristics of Honeybee (Apis mellifera L.) Housed in Heated, Fan Wooden and Insulated Beehives. J. Anim. and Vet. Advances, 8(8): 1516- 1519.

11. 11-Esch, H. E., F. Goller and B. Heinrich. 1991. How do bees shiver? Naturwissenschaften, 78: 325-328.

12. Furgala, B. and D.M. McCutcheon. 1992. Wintering productive colonies In: Graham, J., M., (Ed.), The Hive and the Honey bee, Dadant \& Sons, Hamilton, IL: 829-868.

13. Hoopingarner, R. H., and G. D., Waller. 1992. Crop pollination. In: Graham, J., M. (Ed.), The hive and the honey bee. Dadant \& Sons, Hamilton, IL., pp. 10431082.

14. Jones, J. C., and B. P. Oldroyd. 2007. Nest thermoregulation in social insects. Advances in Insect Physiology, 33, 153-191.

15. Joshi N.C., and P.C. Joshi. 2010. Foraging behaviour of Apis spp. on apple flowers in a subtropical environment. NY Sci. J. 3: 71-76.

16. Kleinhenz, M., B. Bujok., S. Fuchs., and J. Tautz. 2003. Hot bees in empty broodnest cells: heating from within. J. Exp. Biol. 206 (23) : 4217-4231.

17. Marco Kleinhenz1, B. B., F. Stefan and T. Jürgen. 2003. Hot bees in empty broodnest cells: heating from within. The Journal of Experimental Biology 206: 4217-4231.

18. Mathis, C. R., and D. R. Tarpy. 2007. 70 million years of building thermal envelope experience: Building science lessons from the honeybee.

19. Ojeleye B, 1999. Foundation of Beekeeping in the tropics. CEBRAD press Ibadan Nigeria :1-225.

20. Petz Stabentheiner M. A. and K., Crailsheim. 2004. Respiration of individual honeybee larvae in relation to age and ambient temperature. J. Compar. Physiol. B 174: 511-518.

21. Seeley, T.D. 1995. The Wisdom of the Hive: The Social Physiology of Honey Bee Colonies. Harvard University Press, Cambridge, MA.

22. Stabentheiner, A., H. Pressl., T. Papst., N. Hrassnigg. and Crailsheim, K. 2003. Endothermic heat production in honeybee winter clusters. The Journal of Experimental Biology 206, 353-358.

23. Starks, P.T., C.A. Blackle. and T.D. Seeley. 2000. Fever in Honeybee Colonies. Naturwissenschaften, 87:229-231. 
24. Tautz J., S. Maier., C. Groh., W. Rossler and A. Brockman. 2003. Behavioral performance in adult honey bees is influenced by the temperature experienced during their pupal development. Proc. Natl. Acad. Sci. USA 100: 7343-7347.

25. Van Benthem, F D J, V L. Imperatriz-Fonseca and H H W. Velthuis. 1995. Biology of the stingless bee Plebeia remota (Holmberg): observations and evolutionary implications. Insects Sociaux 42(1): 71-87.

26. Velthuis, H H W; D, Koedam and V L, Imperatriz-Fonseca. 2000. The rate of brood cell production in the stingless bee Melipona bicolor fluctuates with nest box temperature. Revista de Etologia 2(1): 141-145.

27. Wineman, E., Y. Lenski and Y. Mahrer. 2003. Solar heating of honeybee colonies (Apis mellifera L.) during the subtropical winter and its impact on hive temperature. worker population and honey production. Am. Bee J., 143: 565570. 


\section{تأثير الحيز الااخلي والعزل الحراري للخلية علي قوة و إنتاجية طوائف النحل}

بهاء الدين حميدة عبد الموجود محمد علي إبر اهيم الراجي أحمد أسامه الأشهب

$$
\text { معهد بحوث الهندسة الزراعية - مركز البحوث الزراعية - دقى - جيزة - مصر }
$$

أجريت الدر اسة لملاحظة تأثثر الحيز الداخلي و العزل الحراري للخلية علي قوةطو ائف النحل

وذللك بتقدير مساحة الحضنة المنتجة وكذلك إنتاجية طو ائف النحل من خلال معرفة مساحة كلا من العسل وحبوب اللقاح المخزنة بالبراويز بالإضافة إلي ملاحظة التغير في درجات الحرارة داخل الخلية.لإجر اء ذلك استخدمت خلايا من نوع لانجستروس تحتوي طو ائف نحل من النوع الهجين

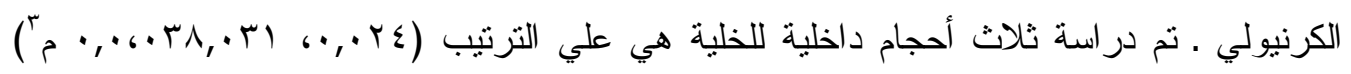
وثلاث حالات للعزل هي (بدون عزل ، خبش ، فوم) وثلاث اتجاهات لباب الخلية هي (شرقي،

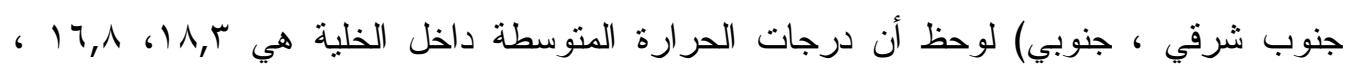

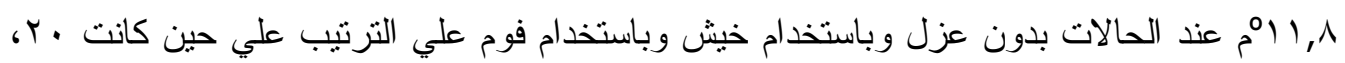
(7, الاتجاهات التالية لباب الخلية (جنوبي ، جنوب شرقي ، شرقي) وذلك تقريبا في منتصف شهر يناير •

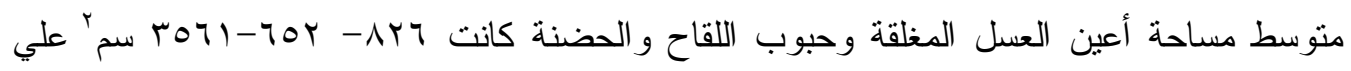

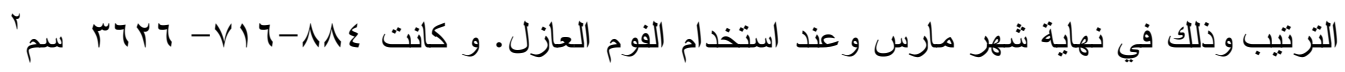

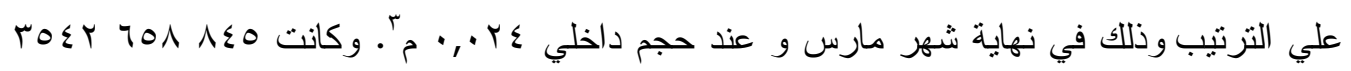
سم علي الترتيب وذلك في نهاية شهر مارس و عند الاتجاه الجنوبي لباب الخلية. لذا فانه عند استخدام اقل حجم داخلي للخلايا و الفوم كمادة عازلة فان هنالك زيادة في درجة حر ارة الخلية الداخلي ومساحة

$$
\text { أعين العسل المغلقة وحبوب اللقاح و الحضنة. }
$$

